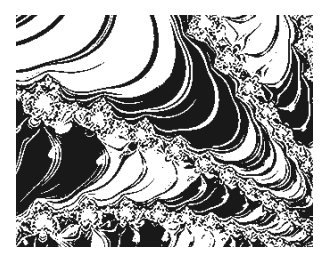

https://doi.org/10.5559/di.29.2.03

\title{
HEALTH-RISK BEHAVIOURS IN OBJECTIVE AND SUBJECTIVE HEALTH AMONG CROATIANS AGED 50 AND OLDER
}

Tatjana ŠKARIĆ-JURIĆ, Nina SMOLEJ NARANČIĆ Institute for Anthropological Research, Zagreb Šime SMOLIĆ Faculty of Economics and Business, Zagreb

UDK: 316.62-053.88/.9(497.5):613.9

Izvorni znanstveni rad

Primljeno: 6. 4. 2018.

Recent data indicate that self-rated health among Croatians is substantially lower, and the gender gap more pronounced, than the EU28. Thus, our study aims to test the sex-specific associations of various health-risk characteristics with subjective and objective health in the Croatian population aged 50 and older $(2,436$ individuals, cross-sectional SHARE Wave 6 dataset). The logistic regression analyses were performed on health-risk behaviours (nutrition, physical activity, smoking, and alcohol consumption), together with the selected socioeconomic variables and the quality of life scale (CASP-12). The study revealed the importance of vigorous physical activity and the CASP score as being consistently relevant for objective and subjective health in both sexes. Univariate associations of the majority of health-risk behaviours and health have disappeared from the multivariate model; we have thus concluded that they are often a proximate reflection of underlying economic and psychosocial factors. Furthermore, our findings support the necessity of country-specific health-risk research since the relevance of particular health risks can be considered culturally specific.

Keywords: SHARE, health-risk behaviour, self-rated health, socioeconomic status, quality of life

Tatjana Škarić-Jurić, Institute for Anthropological Research, Gajeva 32, 10000 Zagreb, Croatia. 
The myriad of epidemiological studies carried out since the end of WWII have shown that behavioural patterns have important health consequences. This is especially attributable to so-called health-risk behaviours (health-related behaviours or lifestyle risk factors), among which smoking, low levels of physical activity, and obesity are prominent (e.g. Leon \& Connett, 1991; Vita, Terry, Hubert, \& Fries, 1998; Danaei et al., 2009; Reuser, Bonneux, \& Willekens, 2009; Chakravarty et al., 2012; Södergren, 2013).

In recent decades, there has also been growing evidence pointing to non-traditional risk factors for chronic disease development and mortality prediction relating to socioeconomic and psychological characteristics. Among them, health and mortality relations with psychosocial elements, education level, employment status, and wealth/poverty have been recognised (e.g. Engelhardt, Buber, Skirbekk, \& Prskawetz, 2010; Fernandez-Martinez et al., 2012; Čipin \& Smolić, 2013; Zhang, Bago D'Uva, \& van Doorslaer, 2015; Segel-Karpas, 2015; Pongiglione \& Sabater, 2016; Arezzo \& Giudici, 2017; Schmitz \& Pförtner, 2017; Stolz, Mayerl, Waxenegger, \& Freidl, 2017).

Croatia's participation (2015) in the Survey of Health, Ageing and Retirement (SHARE) study starting with Wave 6 offered the opportunity to analyse the associations between traditional behavioural risk factors with subjective and objective health in the country-representative sample of people aged 50 and older, as well as to evaluate the health importance of a number of economic and psychosocial factors.

Although the rationale to exploit the sample of individuals aged 50 and older lies in the design of the SHARE study, we find this age range to be important in exploring health and health behaviour for several reasons. One of them is a dramatic increase in single-person households in developed countries after the age of 50, which is one of the most visible signs of societies' ageing (Reher \& Requena, 2018). This change in family structure affects individuals' health status and increases the risk of health behaviours or the utilisation of health services etc. (Iliffe et al., 1992; Isengard, 2013). While the health of older people is likely to deteriorate faster than that of younger people, in addition to having a higher probability of being disabled, the older population has a greater demand for health care and total health expenditure (Reinhardt, 2003). Therefore, policymakers are concerned that the rapidly ageing population will increase public expenditure on long-term care (Thomeer, Mudrazija, \& Angel, 2016); this is supported by the empirical finding that per capita health expenditure is higher for older than younger people. 
DRUŠ. ISTRAŽ. ZAGREB GOD. 29 (2020), BR. 2, STR. 217-239

ŠKARIĆ-JURIĆ, T. SMOLEJ NARANČ́IĆ, N., SMOLIĆ, Š: HEALTH-RISK...
It is critical to emphasise that the disease and medical care usage patterns differ between genders (Haveman \& Wolfe, 2000): in the European context, men have a higher risk of fatal diseases, whereas women are more likely to experience less fatal but more disabling diseases (Avenado \& Mackenbach, 2008). Considering medical care usage, in younger age groups women tend to use more medical services; however, they seem to be healthier in the long run. Santos-Eggimann, Junod, and Cornaz (2005) indicate that a high level of health care utilisation is correlated with old age, and women report significantly more medical consultations and are prescribed more medications than men. The female elderly population exceeds the male one, and so this has led to the adaptation of the healthcare system to this dominant population group.

In addition to objective, medically diagnosed health, a simple instrument, 'self-rated health', has been created in order to evaluate an individual's overall health status. This instrument is widely exploited in cross-country comparisons of populations' health. It has been documented that self-rated health is a measure of relatively high stability and is a strong predictor of mortality (Miilunpalo, Vuori, Oja, Pasanen, \& Urponen, 1997; DeSalvo, Bloser, Reynolds, He, \& Muntner, 2006; Jylhä, 2009). There is a cumulative effect of one's previous life-course on the self-rated health since it is influenced by both objective health status and an awareness of the behavioural factors that influence health (Abuladze, Kunder, Lang, \& Vaask, 2017), alongside other psychosocial factors.

Interdisciplinary health studies have evidenced that there are discrepancies between self-rated and medically obtained health status information and that they have often been associated with social and demographic factors such as gender or age (Idler \& Benyamini, 1997). These findings imply that the respondents' perceptions of their health status include information on their medical status, but that information is evaluated differently by men and women in distinct social positions. It is vital to mention that poor health ratings in men are more predictive of mortality than such ratings in women (Benyamini \& Idler, 1999; Deeg \& Kriegsman, 2003), pointing to the gender differences in the evaluation of one's own health.

There is also clear evidence that health self-rating differs among European countries and these differences may be explained by the long-term socioeconomic history of a particular country (east-west gap) (Huijts, Perkins, \& Subramanian, 2010; Witvliet, Arah, Stronks, \& Kunst, 2014). Worse self-rated health and a larger gender gap in the Croatian population compared to EU28's mean values (Eurostat, 2018; Figure 1) provoke a further search for the determinants of such findings. 


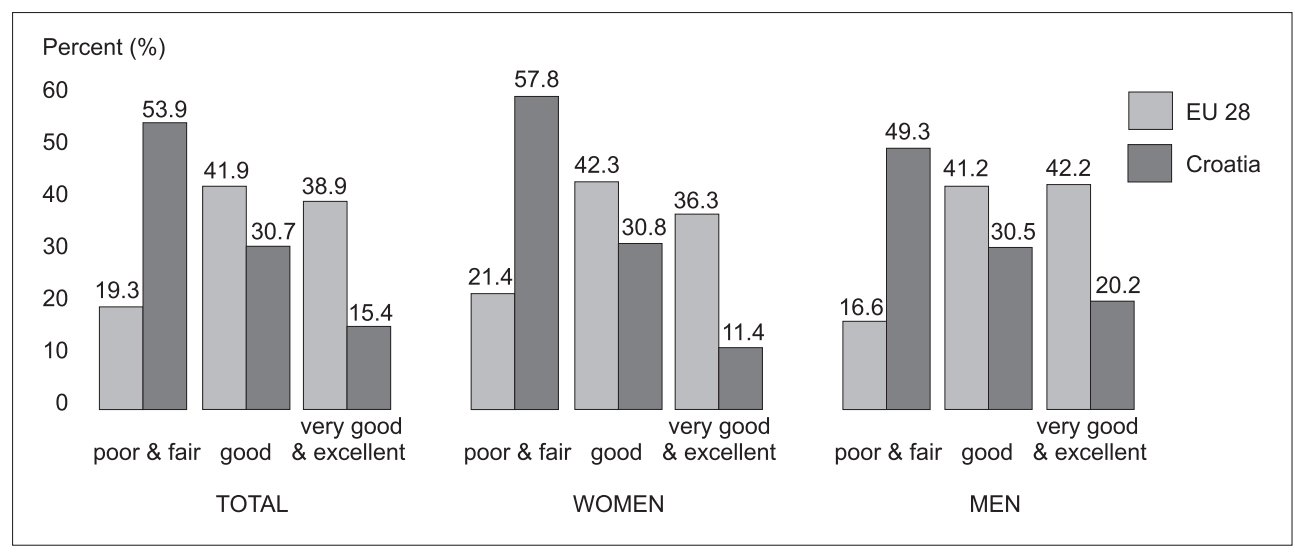

i) FIGURE 1

Self-rated health in populations of $28 \mathrm{EU}$ countries and Croatia aged 65 years and older. Sources: EU28 data for 2016 : EUROSTAT (2018); Croatian data from Wave 6 SHARE (present study)
A preliminary study performed by Smolić (2017) explored the relations of health-risk behaviours with self-rated health in an overall sample of Croatians aged 50 and older. Building on these findings, the present study is particularly interested in exploring the health-risk associations with subjective in contrast to objective health, as well as in the possible gender differences.

Additionally, the associations of traditional behavioural risk factors (nutritional habits, physical activity, smoking, and alcohol consumption) with health have been examined in conjunction with a set of economic, social, family, and quality of life characteristics in order to elucidate the independent relations of health-risk behaviours with subjective and objective health. Namely, the association of the explored non-behavioral factors with health might be direct but also indirect in the manner that they are potentially related to some behavioral patterns (Lara, McCrum, \& Mathers, 2014; Havigerová, Dosedlová, \& Burešová, 2018).

Consequently, the specific aims of the present study are to explore for each gender individually:

(1) the prevalence of health-risk behaviours in the representative sample of the general population of Croatia aged 50 years and older;

(2) the health-risk behaviours as well as economic and psychosocial characteristics associations (univariate and multivariate) with subjective and objective health.

\section{METHODS}

\section{Data}

In Croatia, the SHARE study was conducted for the first time in 2015 within Wave 6 (the study protocols are explained in detail in Börsch-Supan et al., 2013; Malter \& Börsch-Supan, 2017). Croatia's participation in SHARE enabled it to gather, using a country-representative sample of adult persons aged 
DRUŠ. ISTRAŽ. ZAGREB GOD. 29 (2020), BR. 2, STR. 217-239

ŠKARIĆ-JURIĆ, T. SMOLEJ NARANČ́IĆ, N., SMOLIC, S.: HEALTH-RISK...
50 and older and their partners, a rich dataset from which we have utilised the Behavioral Risks and Physical Health modules (Börsch-Supan, 2017). Additionally, the easySHARE dataset (Börsch-Supan, Gruber, Hunkler, Stuck, \& Neumann, 2017) was used for the selected economic and psychosocial indicators since it contains a profiled subset of indices and scores that are internationally used, thus ensuring cross-country and cross-wave comparability. In our analyses we included the data from 2,436 individuals with complete information $(1,085$ men and 1,351 women) out of the 2,494 interviewed.

Two key binary outcome variables ('good health' and 'poor health') that present subjective and objective health indicators were specifically constructed for the purpose of this paper. The subjective health indicator was developed from a self-rated health measure with a five-point scale. Participants answering 'excellent', 'very good', or 'good' were placed in the 'good health' group, or group 1, while those who answered 'fair' or 'poor' were placed in the 'poor health' group, or group 2.

The second key outcome variable - the objective health indicator - was constructed using principal component analysis (PCA). This is a multivariate method systematically identifying the underlying variables, or principal components, that best differentiate a set of data. PCA included several available physical health variables that, in various ways, objectively describe participants' health status. The following six variables were entered into the PCA: the number of diseases (the sum of positive answers: 'You have been medically diagnosed with...' for the 21 specific chronic medical conditions), the number of physical limitations in everyday activities (the sum of positive answers for 10 activities of daily living (ADL) limitations), the number of limitations in everyday activities (the sum of positive answers for 15 instrumental activities of daily living (IADL) limitations), the number of signs of frailty (the sum of positive answers for six signs), grip strength (the mean value of two measurements on both hands), peak flow (the mean value of two measurements of the respondent's expiratory lung force). PCA was performed on a smaller number of highly informative variables, in order to avoid the dispersal of information on several components due to the large number of highly correlated physical health variables. The PCA was conducted for each sex separately and the sample was subsequently split into two groups according to the first component scores (above and below zero factor score values), with group 1 encompassing the participants with better health ('good health' group), and group 2 those with worse health ('poor health' group). 


\section{Statistical methods}

Sex differences were tested using t-tests for continuous variables and by $\chi^{2}$-tests for categorical/ordinal ones. The association of the selected independent variables with the health outcome was tested by means of univariate and multivariate logistic regression analyses, for each sex separately. Namely, this is a multivariate method which facilitates the simultaneous analysis of the association of both continuous and categorical/ordinal independent variables on the outcome variable (health indicator). This analysis, in addition to age, included 11 variables from the SHARE Behavioral Risks module, which were in a narrow sense considered as behaviours and habits related to health. In order to explore whether the influence of the health-risk behaviours on health is independent or whether they are a reflection of psychosocial, economic, and family factors, the model also included nine variables from the easySHARE dataset representing social, economic, and family factors, as well as a composite variable that described respondents' self-rated quality of life (CASP-12 scale). CASP-12 is a modification of the CASP-19 scale made by SHARE; it measures respondents' quality of life and is based on four sub-scales on control, autonomy, pleasure, and self-realisation (Borrat-Besson, Ryser, \& Gonçalves, 2015). The answers are coded on a four-point Likert scale (1 often, 2 sometimes, 3 rarely, and 4 never) and all items are recoded in such a way that higher scores indicate a higher quality of life.

The majority of the independent variables included in the logistic regression were alternatively tested in their continuous/ ordinal and binary forms (e.g. household size/living alone, location/living in a rural setting, income in percentiles/income below the 50th percentile, and pack-year/pack-year in three categories (never-smoker, light smoker, heavy smoker). Finally, the forms of variables that participated in the best of the tested models were selected, meaning, the model (here presented) that explained the largest proportion of variance.

\section{RESULTS}

\section{Descriptive results}

Table 1 presents the ranges of values and descriptive statistics for the analysed variables. The data are shown for men and women separately, and the indicators of significance of sex differences are provided (as obtained by t-test for continuous variables and by $\chi^{2}$-test for categorical/ordinal ones). Age (ranging from 50 to 95 years) did not differ significantly between men $(65.3 \pm 8.7)$ and women $(65.2 \pm 9.7)$. The objective health 
DRUŠ. ISTRAŽ. ZAGREB GOD. 29 (2020), BR. 2, STR. 217-239

ŠKARIĆ-JURIĆ, T. SMOLEJ NARANČ́IĆ, N., SMOLIĆ, Š.

HEALTH-RISK.. distribution was the same in both sexes. This finding was expected, keeping in mind that objective health was formed using a PCA carried out for each sex separately. On the other hand, the distribution of subjective health indicators was significantly different between the sexes, with a higher percentage of men in the 'good health' group (58.3\% vs. 53.5\%). This is a consequence of the distribution of original self-rated health answers in which men rated their health as excellent $(9.5 \%$ vs. $5.5 \%)$ or very good $(18.7 \%$ vs. $16.7 \%)$ more frequently, while women more often described their health as poor $(20.8 \%$ vs. $16.8 \%)\left(\chi^{2}=19.646 ; d f=4 ; p=0.001\right)$.

\begin{tabular}{|c|c|c|c|c|c|}
\hline Variables & Min. & Max. & $\begin{array}{r}\text { Women } \\
\text { Mean }(S D), \%\end{array}$ & $\begin{array}{r}\text { Men } \\
\text { Mean }(S D), \%\end{array}$ & $p$ \\
\hline Objective Health (\%1: 'good health') \# & 1 & 2 & 61.3 & 62.4 & \\
\hline Subjective Health (\%1: 'good health')\# & 1 & 2 & 53.5 & 58.3 & * \\
\hline Age (years) & 50 & 95 & $65.2(9.7)$ & $65.3(8.7)$ & \\
\hline $\mathrm{BMI}\left(\mathrm{kg} / \mathrm{m}^{2}\right)$ & 15.1 & 49.4 & $27.2(4.6)$ & $27.7(4.1)$ & ** \\
\hline Frequency of serving dairy products ( $\% 1$ : every day) & 1 & 5 & 56.6 & 46.4 & $* * *$ \\
\hline Frequency of serving legumes or eggs ( $\% 1$ : every day) & 1 & 5 & 11.0 & 11.2 & \\
\hline Frequency of serving meat, fish or chicken (\% 1: every day) & 1 & 5 & 36.4 & 41.8 & * \\
\hline Frequency of serving fruits or vegetables ( $\% 1$ : every day) & 1 & 5 & 78.3 & 69.3 & $* * *$ \\
\hline Units of alcoholic drink in the last 7 days (\%1: none) $)^{\#}$ & 1 & 3 & 78.3 & 46.1 & $* * *$ \\
\hline Frequency of $\geq 6$ drinks in the last 3 months ( $\% 7$ : not at all) & 1 & 7 & 93.9 & 73.0 & $* * *$ \\
\hline Smoke at the present time (\%1: yes) & 1 & 2 & 19.5 & 26.9 & $* * *$ \\
\hline Cumulative life-long smoking pack-years (pack-years)\# & 0 & 160 & $6.5(13.0)$ & $19.9(25.3)$ & $* * *$ \\
\hline Vigorous activities (\%1: more than once a week) & 1 & 4 & 31.1 & 37.0 & $* * *$ \\
\hline Moderate activities (\%1: more than once a week) & 1 & 4 & 67.5 & 69.1 & \\
\hline Education (years) & 0 & 25 & $9.7(4.0)$ & $11.2(3.4)$ & $* * *$ \\
\hline Household income (percentiles) ${ }^{\dagger}$ & 1 & 10 & $5.3(2.8)$ & $5.8(2.9)$ & $* * *$ \\
\hline Current employment situation (\%1: not working) $)^{\text {†\# }}$ & 1 & 2 & 83.5 & 77.2 & $* * *$ \\
\hline Area of living (\% 1 : big city) ${ }^{\dagger}$ & 1 & 5 & 11.1 & 11.3 & \\
\hline Household size (number of members) ${ }^{\dagger}$ & 1 & 11 & $2.4(1.3)$ & $2.6(1.3)$ & ** \\
\hline Number of children ${ }^{\dagger}$ & 0 & 10 & $1.9(1.1)$ & $1.9(1.0)$ & \\
\hline Number of grandchildren ${ }^{\dagger}$ & 0 & 25 & $2.7(2.5)$ & $2.3(2.1)$ & $* * *$ \\
\hline At least one child lives less than $1 \mathrm{~km}$ away $(\% 1: \mathrm{no})^{\dagger}$ & 1 & 2 & 34.1 & 36.4 & \\
\hline CASP-12 (score) $)^{\dagger}$ & 15 & 48 & $35.4(6.6)$ & $36.7(6.2)$ & $* * *$ \\
\hline
\end{tabular}

Legend: $\uparrow$ - variable from easySHARE database; \# - categorised or calculated variables from the original ones. ${ }^{*} p \leq 0.05 ;{ }^{* *} p \leq 0.01 ;{ }^{* * *} p \leq 0.001$

(1) TABLE 1

Descriptive statistics of analysed variables separately for men $(\mathrm{N}=1.085)$ and women $(\mathrm{N}=1.351)$ Sex differences are tested by t-test for continuous variables and by chi $^{2}$-test for categorical/ordinal ones
The variables indicating health-related behaviours showed a clear sex-specific pattern. Considering nutritional habits, the two sexes differed; women more frequently consumed dairy products, fruits, and vegetables, while men more frequently consumed meat, fish, and chicken (the sexes did not differ in the consumption frequency of legumes or eggs). Men consumed alcohol more often than women (one to five units of alcohol in the last seven days: $22.4 \%$ vs. $15.0 \%$; six or more units: $31.5 \%$ vs. $6.7 \%$ ). At the same time, men were more likely to consume an excessive quantity of drinks (six or more drinks in one day, at least once in the last three months: $27.0 \%$ vs. $6.1 \%$ ). 


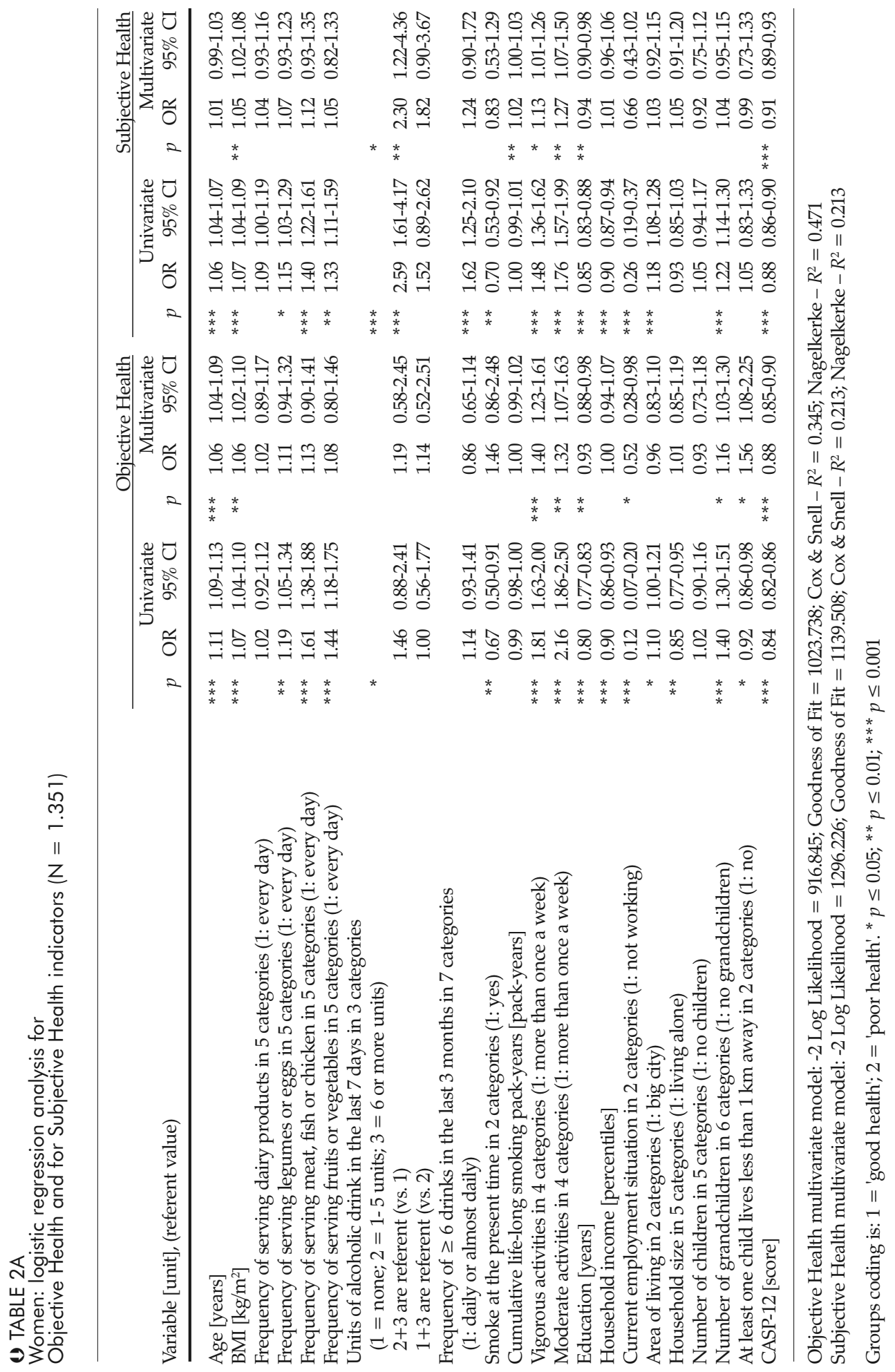







DRUŠ. ISTRAŽ. ZAGREB

GOD. 29 (2020), BR. 2,

STR. 217-239

ŠKARIĆ-JURIĆ, T.

SMOLEJ NARANČ́IĆ, N.,

SMOLIĆ, Š.:

HEALTH-RISK...
Men were also more likely current smokers (26.9\% vs. $19.5 \%)$ and they had a much higher life-long cumulative exposure to cigarettes, as measured by the pack-year variable $(19.9+25.3$ vs. $6.5+13.0$ ), which is calculated as: (smoking years $x$ daily number of cigarettes)/20. On average, men also had a slightly higher body mass index (BMI) $(27.7 \pm 4.1$ vs. $27.2 \pm 4.6)$. Men more frequently practised sports or vigorous physical activities, but there was no sex difference in the frequency of practising activities requiring a moderate level of energy.

Considering additional socioeconomic, family, and quality of life factors, the two sexes differed in the following ways: men reported a higher household income (5.8 vs. 5.3 percentile), they also had more years of education (11.2 vs. 9.7), and were more likely to be working (22.8\% vs. $16.5 \%)$. Men also reported a larger household size ( 2.6 vs. 2.4 members), while women had more grandchildren ( 2.7 vs. 2.3 ). There were no sex differences considering the area in which they lived, their number of children, or the frequency of having at least one child living less than $1 \mathrm{~km}$ away. Finally, it seems that quality of life and well-being was judged as better by men in comparison to women. Namely, men had responded more positively to questions relating to the four different indicators that in combination comprise the CASP index (36.7 vs. 35.4 CASP-12 mean scores).

\section{The determinants of objective and subjective health in women}

The univariate and multivariate relations of the selected independent variables with dependent key outcome variables applying the logistic regression analysis are presented for women and men in Tables $2 \mathrm{~A}$ and $2 \mathrm{~B}$, respectively. For women, the majority of the examined independent variables demonstrated a univariately significant relation with the dichotomous objective health variable (Table $2 \mathrm{~A}$ ). However, many of those variables ceased to be significantly related to health when considered within the multivariate model; this is because they were obviously correlated with other examined variables that had a more important impact on belonging to the 'healthy/ not healthy' categories. Therefore, when analysing variables within the frame of the multivariate model, we could judge the importance of particular variables for health more realistically.

In the multivariate model, age and BMI retained their negative relations to objective health in such a way that higher age and BMI increased the odds of belonging to the group of persons with 'poor health' by 1.06 in both variables. Among 
DRUŠ. ISTRAŽ. ZAGREB GOD. 29 (2020), BR. 2, STR. 217-239

ŠKARIĆ-JURIĆ, T. SMOLEJ NARANČ́IĆ, N., SMOLIĆ, Š.: HEALTH-RISK... activity retained their significance in the multivariate model: practising physical activity - be it vigorous or moderate - less than once a week increased the odds of belonging to the 'not healthy' group by 1.40 and 1.32, respectively. The significance of nutritional variables disappeared within the multivariate model that included other social, economic, family, and psychological variables.

Of the nine socioeconomic and quality of life variables, a significant relation with objective health in the multivariate analysis was found for the following: years of education, current employment, and higher CASP score. All these factors increased the odds of belonging to the 'good health' group. On the other hand, the odds of belonging to the 'poor health' group were increased by having at least one child living within $1 \mathrm{~km}$ and an increased number of grandchildren. Since we cannot reveal the causative mechanisms of the latter relation that most likely comprise factors acting outside of the variables currently being examined, we can simply remark that a larger number of grandchildren was positively correlated with age $(r=0.398)$. It can be speculated that the significant relation between health status and number of grandchildren resulted from the remaining part of the age correlation, since age as a variable was also included in the model.

Similarly to objective health, in the case of subjective health the majority of the examined variables showed significant univariate relations. Moreover, in the multivariate analyses, the following variables were in the same manner related to subjective health: BMI and both variables describing the frequency of physical activity. Among the socioeconomic variables, subjective and objective health were both related with only two variables: years of education and CASP score. On the other hand, compared to objective health, subjective health was not found to be significantly related to employment status, number of grandchildren, and at least one child living within $1 \mathrm{~km}$. It is interesting to note that age was not shown to be an important factor for the subjective health rating in the multivariate model.

A particularly noteworthy finding was the emergence of behavioural variables that were significantly related to subjective health in the multivariate model and that were not importantly related to objective health: the amount of alcohol consumed (units of alcohol in the last seven days across three categories) and pack-year, which contained information about the cumulative number of cigarettes smoked during the respondent's lifetime. The direction of this relation is also interesting; women with higher pack-years, i.e. who smoked more during 
DRUŠ. ISTRAŽ. ZAGREB

GOD. 29 (2020), BR. 2,

STR. 217-239

ŠKARIĆ-JURIĆ, T.

SMOLEJ NARANČ́IĆ, N., SMOLIĆ, Š.:

HEALTH-RISK... their lives, are more likely to rate their health negatively, i.e. to belong to the 'poor health' group. On the other hand, the same health group comprised women who answered 'none' to 'the amount of consumed alcohol in the last week' question. In other words, not drinking alcohol at all (total abstinence) increased the odds of belonging to the 'poor health' group by 2.30 .

\section{The determinants of objective and subjective health in men}

After examining the relations of independent variables with objective health in men (Table 2B), it is obvious that from the number of univariately identified significant relations, only age and two behavioural variables remained significant in the multivariate model: vigorous sport activities and alcohol units consumed in the last seven days across three categories. The direction of the relationship of the aforementioned variables with health was the same in men and women, and therefore is not specified here again. From the extended set of variables in the multivariate model, three proved to be significant. Household size and number of grandchildren were related to health in such a way that the increase of both brought higher odds of 'poor health'. On the other hand, an increase in the CASP score decreased the odds of belonging to the 'poor health' group by 0.85 .

A common finding in both sexes was the age and number of grandchildren (negative influence) and sports or vigorous activities and CASP score (positive influence) variables' significant relations to objective health. It is vital to note that, compared to women, the multivariate model for men did not identify variables such as BMI or activities requiring a moderate level of energy, as well as the number of years of education, employment status, and at least one child living within $1 \mathrm{~km}$, as significantly related with the objective indicator of health.

Considering subjective health, in the multivariate model only two health-risk behaviours retained their significance: vigorous physical activities and units of alcohol taken weekly; the relation was the same as that in women. Complete abstinence from alcohol consumption increased the odds of belonging to the 'poor health' group by 2.30 in women and by 1.59 in men (Table 2). This relation is also displayed in Figure 2 , where it is clear that a higher percentage of people with poor health compared to good health are found within the first alcohol category (the category answering 'none' to 'How many units of alcohol have you drunk in the last seven days?'). From the behavioural set, one variable emerged as significant in the multivariate model: the frequency of consum- 
ing fruits and vegetables. It is interesting that the latter variable was negatively related to health, i.e. less frequent consumption of fruits and vegetables increased the odds of belonging to the 'good health' group by 0.80 .

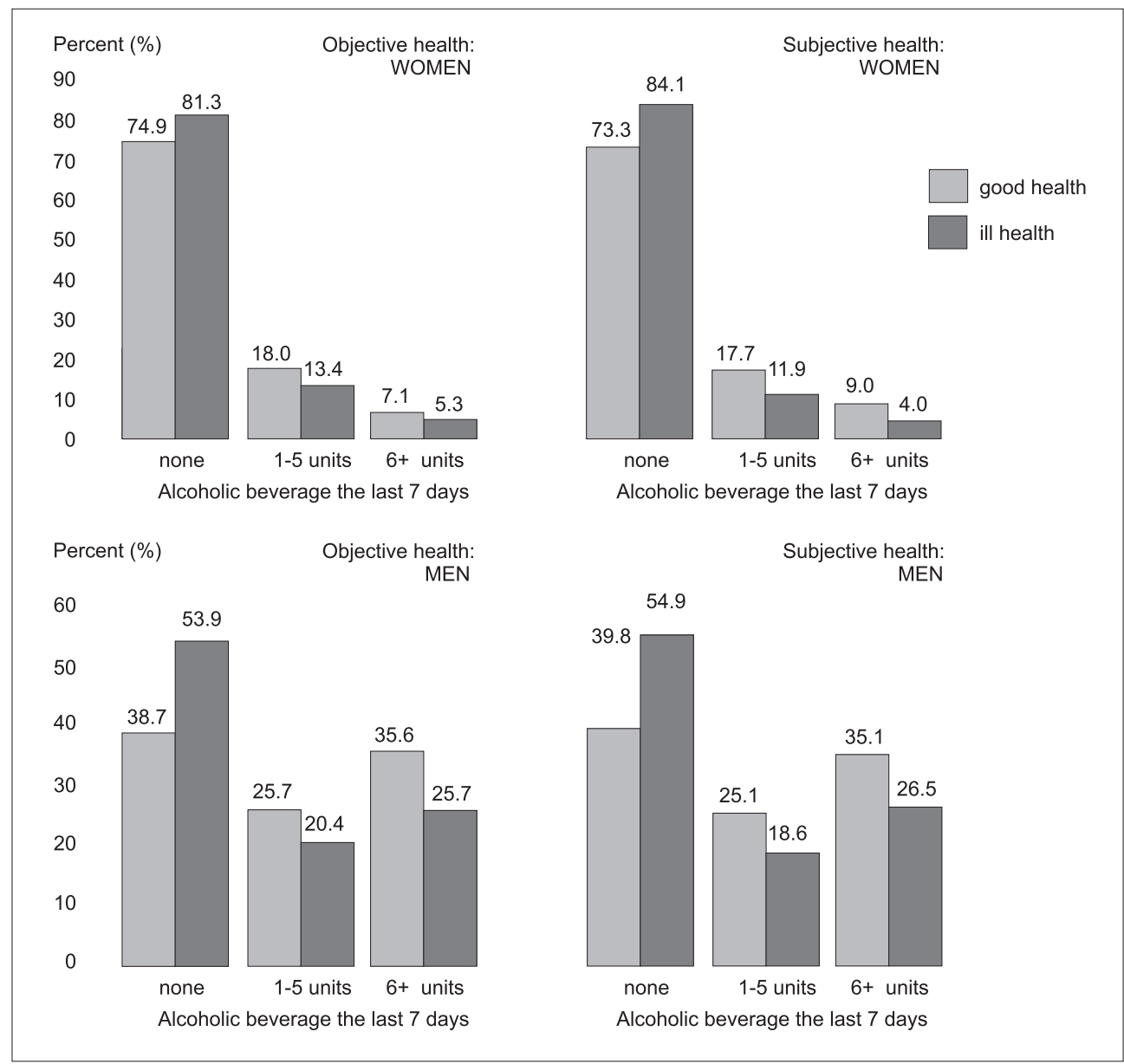

\section{(1) FIGURE 2}

Weekly consumption of alcohol in Croatian population aged 50 years and older by sex and health status
The data are presented as the percentage of good health / poor health persons belonging to one of the three alcohol consumption categories $(1=$ none; $2=$ one to five units; $3=$ six or more units of alcoholic beverage in the last seven days)

Out of the socioeconomic variables, only the CASP score showed the same significant relation to health in subjective and objective health. A thought-provoking finding was that two variables - years of education and location - showed a significant relation to subjective health, but were not important for objective health. Conversely, there were two variables - household size and number of children - that showed a significant relation to objective health, but were not found to be significant for subjective health. 
We present the sex-specific patterns of relations of potentially important behavioural, socioeconomic, family, and personal characteristics with subjective and objective health in Croatians aged 50 or older. This study is based on the SHARE Wave 6 data, and the results presented here might serve as a starting point for future research, once the longitudinal SHARE data for Croatia becomes available.

The association between socioeconomic factors and health in Croatia was earlier explored in several studies, e.g. in the study of health inequalities, where the differences in health status were considered by determinants such as income and educational level (Šućur \& Zrinščak, 2007; Čipin \& Smolić, 2013), or in the study of the association between subjective physical and mental health and employment status (Šverko, Galić, \& Maslić Seršić, 2006; Galić \& Šverko, 2008). The most recent study of Bjelajac et al. (2019), exploiting SHARE Wave 6 data, analysed the benefits of participation in the active workforce to mental health for Croatians aged 50 to 65 years.

The health behaviour variables were studied in Croatia within the course of several nationally representative projects: The First Croatian Health Project (1995-1997) (Turek et al., 2001), Croatian Health Survey (1997-1999) and the Croatian Adult Health Survey (CAHS) conducted in 2003 and 2008 (Vuletić, Polašek, Kern, Strnad, \& Baklaić, 2009), and all of them were primarily aimed at establishing the cardiovascular disease risk factors prevalence. In addition to some demographic, socioeconomic, and health care utilisation variables, the CAHS also assessed the subjective experience of health status using the Short Form 36 Health Survey questionnaire (SF-36). The first nationally representative study in Croatia (for persons aged 15 and over) that analysed the association between self-rated health on the one hand, and lifestyle, demographic and socioeconomic factors on the other, was the second wave of The European Health Interview Survey (EHIS 2) that was conducted in 2014/2015, and the results for Croatia were recently published (Ivičević Uhernik et al., 2019). In parallel, Croatia 2015 joined the SHARE study and the first results were published by Smolić (2017), who investigated the association between the self-reported health status of Croatians aged 50 and over with a limited set of physical health variables, controlling for demographic and socio-economic characteristics.

Compared to previous studies, the present study added a new separate analysis for the male and female population aged 50 and over in Croatia, and applied a broader set of explanatory variables. Specifically, we were interested in explor- 
DRUŠ. ISTRAŽ ZAGREB GOD. 29 (2020), BR. 2, STR. 217-239

ŠKARIĆ-JURIĆ, T. SMOLEJ NARANČ́IĆ, N., SMOLIC, S.: HEALTH-RISK... ing whether the relationship of health-risk behaviours to health (as the potentially proximate causative factors) was actually a reflection of other social, economic, or psychological factors (as remote causative factors acting indirectly through health-risk behaviours). A detailed exploration and interpretation of the causative relations of particular variables with health and disease, should be the focus of future, more profiled research.

In the multivariate logistic regression analysis, the frequency of performing sports or vigorous physical activities and CASP score were the only two out of the tested variables that were significantly related to both objective and subjective indicators of health in both men and women. We should point out here the established relevance in the present study of the CASP score for subjective and objective health in both sexes. This score (measuring quality of life and life satisfaction) was independent of all other factors, since the significance and odds ratios in all four logistic regression analyses were practically identical to those obtained when considered univariately (odds ratios ranging from 0.83 to $0.91 ; p<0.0001$ in all analyses).

In light of the fact that within the set of behavioural variables in the multivariate model only vigorous physical activity consistently demonstrated a strong positive correlation with health, it is interesting to note that in women (but not in men) moderate physical activity also showed a significant positive correlation with good health. Aside from physical activity, none of the other behavioural characteristics revealed such a trend. Among them, the strongest correlation was found between the complete abstinence from alcohol and 'poor health'; this emerged in three out of four models, the exception being objective health in women. BMI was significantly related to objective and subjective health indicators in women, but none in men. The remaining significant variable was pack-year, which showed a negative correlation with subjective health in women. Among nutritional habits, the only significant relation with health was found in men and it was a negative correlation between the frequency of consuming fruit and vegetables and subjective health. It seems that in Croatian men aged 50 years and older, fruit and vegetable consumption is primarily considered as a self-administered medicine when subjectively experiencing poor health.

The next most prominent finding was the fact that age was proven to be significantly related with objective health in both sexes, but not so with subjective health. The negative correlation between age and health was an expected finding and was revealed in the present study for objective health. The absence of such a relation for subjective health was an 
DRUŠ. ISTRAŽ. ZAGREB GOD. 29 (2020), BR. 2, STR. 217-239

ŠKARIĆ-JURIĆ, T. SMOLEJ NARANČ́IĆ, N., SMOLIĆ, Š.: HEALTH-RISK... unexpected and not universally present finding (e.g. Fernandez-Martinez et al., 2012). This emphasises the importance of other unconsidered factors for subjective health, which could include social and psychological well-being, such as the presence of depressive symptoms, cognitive performance, social involvement, and social capital, as well as loneliness (Engelhardt et al., 2010; Segel-Karpas, 2015; Memel, Bourassa, Woolverton, \& Sbarra, 2016; Arezzo \& Giudici, 2017; Richard et al., 2017). However, it is possible that some variables - such as pack-years in women and fruit consumption in men - which were not univariately significant within our multivariate model, have formed a significant part of age relations.

The prevalence of particular behavioural risk factors varies by country (e.g. Avendano \& Mackenbach, 2008; Abuladze et al., 2017; García-Muñoz, Neuman S., \& Neuman T., 2018). This is related to numerous cultural factors, including religiosity (Linardakis et al., 2015), nutritional habits (explaining north-south differences, e.g. Mediterranean nutrition), and smoking and alcohol consumption (e.g. different proportions of hazardous drinkers and alcohol advertising regulations; Bosque-Prous et al., 2017). There are similarities between Croatian findings and those of some other countries, e.g. in Estonia self-rated health is positively associated with life satisfaction, education, and the frequency of physical activities. However, each country has its own specificities. Thus, the elderly in Croatia do not share Estonia's pattern of legume and egg consumption (Abuladze et al., 2017). Smoking, alcohol, and calorie consumption (the latter as measured by BMI) have their individual but also country-specific elements. In their study of those three behavioural risk factors in $16 \mathrm{EU}$ countries participating in SHARE, García-Muñoz et al. (2018) found negative correlations of smoking and obesity with self-rated health. However, similarly to the findings of the present study, those authors found a positive correlation between (moderate) alcohol consumption and subjective health, thus indicating that positive social outcomes (cultural and happiness benefits) outweigh the negative medical ones. Avendano and Mackenbach (2008) point to smoking and low physical activity as the most consistently associated factors with health deterioration among Europeans, whereas a mixed picture emerges for the impact of overweight and alcohol consumption.

From the additional variables that represent social, economic, family, and quality of life factors, the only one that showed a consistent and strong positive relation with health in all four multivariate logistic regression analyses was the CASP score. A higher CASP score, indicating a better quality of life, increased the odds of belonging to the 'good health' 
DRUŠ. ISTRAŽ ZAGREB GOD. 29 (2020), BR. 2, STR. 217-239

ŠKARIĆ-JURIĆ, T. SMOLEJ NARANČ́IĆ, N., SMOLIĆ, Š.

HEALTH-RISK..

\section{CONCLUSIONS}

In the present study of health-risk behaviours and other social, economic, and psychological characteristics, sports or vigorous physical activities and self-rated quality of life (CASP score) stand out because they were vital in both objective and subjective health in women and men in the representative sample of Croatians aged 50 or older. Some findings provoke further considerations since they are important in one sex but not in the other (such as moderate physical activity and BMI for health status in women but not in men) or they emerged as relevant only for objective 'poor health' but not for subjective health (such as age and number of grandchildren). The absence of the commonly established relations with health is just as noteworthy. Among such, the most intriguing findings are the absence of smoking status, nutritional habits, and household income correlations with health.

\section{ACKNOWLEDGEMENTS}

The research was funded by Croatian Science Foundation grant (HRZZ IP-2018-01-2497) to T. Škarić-Jurić. The SHARE data collection has been primarily funded by the European Commission through FP5 (QLK6-CT-2001-00360), FP6 (SHARE-I3: RII-CT-2006-062193, COMPARE: CIT5-CT-2005-028857, SHARELIFE: CIT4-CT-2006-028812) and FP7 (SHARE-PREP: N211909, 
DRUŠ. ISTRAŽ. ZAGREB GOD. 29 (2020), BR. 2, STR. 217-239

ŠKARIĆ-JURIĆ, T. SMOLEJ NARANČ́IĆ, N., SMOLIC, Ś:

HEALTH-RISK... funding from the German Ministry of Education and Research, the Max Planck Society for the Advancement of Science, the U.S. National Institute on Aging (U01_AG09740-13S2, P01 AG005842, P01 AG08291, P30 AG12815, R21 AG025169, Y1-

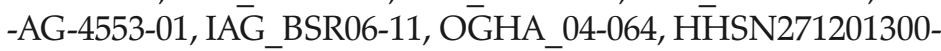
071C) and from various national funding sources is gratefully acknowledged (see: https://www.share-project.org).

Abuladze, L., Kunder, N., Lang, K., \& Vaask, S. (2017). Associations between self-rated health and health behaviour among older adults in Estonia: A cross-sectional analysis. BMJ Open, 7(6), e013257. https://doi. org/10.1136/bmjopen-2016-013257

Arezzo, M. F., \& Giudici, C. (2017). Social capital and self perceived health among European older adults. Social Indicators Research, 130(2), 665-685. https://doi.org/10.1007/s11205-015-1195-z

Avendano, M., \& Mackenbach, J. (2008). Changes in physical health among older Europeans. In A. Borsch-Supan, A. Brugiavini, H. Jürges, A. Kapteyn, J. Mackenbach, J. Siegrist, \& G. Weber (Eds.), Health, ageing and retirement in Europe: First results from the survey of health, ageing and retirement in Europe (2004-2007) (pp. 118-124). Mannheim, Germany: Mannheim Research Institute for the Economics of Aging (MEA). Available at http:// www.share-project.org/uploads/tx_sharepublications/Chapter_4.pdf

Benyamini, Y., \& Idler, E. L. (1999). Community studies reporting association between self-rated health and mortality: Additional studies, 1995 to 1998. Research on Aging, 21(3), 392-401. https://doi.org/10.1177/ 0164027599213002

Bjelajac, A. K., Bobić, J., Kovačić, J., Varnai, V. M., Macan, J., \& Smolić, Š. (2019). Employment status and other predictors of mental health and cognitive functions in older Croatian workers. Archives of Industrial Hygiene and Toxicology, 70(2), 109-117. https://doi.org/10.2478/aiht-201970-3254

Borrat-Besson, C., Ryser, V.-A., \& Gonçalves, J. (2015). An evaluation of the CASP-12 scale used in the Survey of Health, Ageing and Retirement in Europe (SHARE) to measure quality of life among people aged 50+. FORS Working Paper Series, paper 2015-4. Lausanne: FORS. Available at http://forscenter.ch/wpcontent/uploads/2014/06/ FORS_WPS_2015-04_Borrat-Besson.pdf

Börsch-Supan, A. (2017). Survey of Health, Ageing and Retirement in Europe (SHARE) Wave 6. Release version: 6.0.0. SHARE-ERIC. Dataset. https://doi.org/10.1007/978-981-287-082-7_243

Börsch-Supan, A., Gruber, S., Hunkler, C., Stuck, S., \& Neumann, J. (2017). easySHARE. Release version: 6.0.0. SHARE-ERIC. Dataset. https:// doi.org/10.6103/SHARE.easy.600

Börsch-Supan, A., Brandt, M., Hunkler, C., Kneip, T., Korbmacher, J., Malter, F., Schaan, B., Stuck, S., \& Zuber, S. (2013). Data resource profile: The Survey of Health, Ageing and Retirement in Europe (SHARE). International Journal of Epidemiology, 42(4), 992-1001. https://doi.org/ 10.1093/ije/dyt088 
DRUŠ. ISTRAŽ. ZAGREB GOD. 29 (2020), BR. 2, STR. 217-239

ŠKARIĆ-JURIĆ, T. SMOLEJ NARANCIĆ, N., SMOLIĆ, Š:

HEALTH-RISK...
Bosque-Prous, M., Brugal, M. T., Lima, K. C., Villalbí, J. R., Bartroli, M., \& Espelt, A. (2017). Hazardous drinking in people aged 50 years or older: A cross-sectional picture of Europe, 2011-2013. International Journal of Geriatric Psychiatry, 32(8), 817-828. https://doi.org/10.1002/ gps.4528

Chakravarty, E. F., Hubert, H. B., Krishnan, E., Bruce, B. B., Lingala, V. B., \& Fries, J. F. (2012). Lifestyle risk factors predict disability and death in healthy aging adults. The American Journal of Medicine, 125(2), 190-197. https://doi.org/10.1016/j.amjmed.2011.08.006

Coe, N. B., \& Zamarro, G. (2011). Retirement effects on health in Europe. Journal of Health Economics, 30(1), 77-86. https://doi.org/10.1016/ j.jhealeco.2010.11.002

Čipin, I., \& Smolić, Š. (2013). Socio-economic determinants of health in Croatia: Insights from four cross-sectional surveys. Croatian Economic Survey, 15(1), 25-60. https://hrcak.srce.hr/100314

Danaei, G., Ding, E. L., Mozaffarian, D., Taylor, B., Rehm, J., Murray, C. J., \& Ezzati, M. (2009). The preventable causes of death in the United States: Comparative risk assessment of dietary, lifestyle, and metabolic risk factors. PLoS Medicine, 6(4), e1000058. https://doi.org/ 10.1371/journal.pmed.1000058

Deeg, D. J. H., \& Kriegsman, D. M. W. (2003). Concepts of self-rated health: Specifying the gender difference in mortality risk. The Gerontologist, 43(3), 376-386. https://doi.org/10.1093/geront/43.3.376

DeSalvo, K. B., Bloser, N., Reynolds, K., He, J., \& Muntner, P. (2006). Mortality prediction with a single general self-rated health question. A meta-analysis. Journal of General Internal Medicine, 21(3), 267-275. https://doi.org/10.1111/j.1525-1497.2005.00291.x

Engelhardt, H., Buber, I., Skirbekk, V., \& Prskawetz, A. (2010). Social involvement, behavioural risks and cognitive functioning among older people. Ageing $\mathcal{E}$ Society, 30(5), 779-809. https://doi.org/10.1017/S0144 686X09990626

Eurostat - EU Statistical Office (2018). Available at http://europa.eu/ eurostat/web/health/health-status-determinants/data/database (last update 14-02-2018, accessed 26-02-2018)

Fernandez-Martinez, B., Prieto-Flores, M. E., Forjaz, M. J., Fernández-Mayoralas, G., Rojo-Pérez, F., \& Martínez-Martín, P. (2012). Self-perceived health status in older adults: Regional and sociodemographic inequalities in Spain. Revista de Saúde Pública, 46(2), 310-319. https://doi.org/10.1590/S0034-89102012000200013

Galić, Z., \& Šverko, B. (2008). Effects of prolonged unemployment and reemployment on psychological and physical health. Review of Psychology, 15(1), 3-10. https://hrcak.srce.hr/index.php?show =clanak\& id_clanak_jezik $=63731$

García-Muñoz, T., Neuman, S., \& Neuman, T. (2018). Behavioral health risk factors: The interaction of personal and country effects. International Journal of Behavioral Medicine, 25, 183-197. https://doi. org/10.1007/s12529-018-9711-6 
DRUŠ. ISTRAŽ. ZAGREB GOD. 29 (2020), BR. 2, STR. 217-239

ŠKARIĆ-JURIĆ, T. SMOLEJ NARANCIĆ, N., SMOLIĆ, Š.:

HEALTH-RISK..
Haveman, R., \& Wolfe, B. L. (2000). The economics of disability and disability policy, chapter 18. In A. J. Culyer \& J. P. Newhouse (Eds.), Handbook of health economics, Vol. 1 (Part B) (pp. 995-1051). Amsterdam: Elsevier. https://doi.org/10.1016/S1574-0064(00)80031-1

Havigerová, J. M., Dosedlová, J., \& Burešová, I. (2018). One health behaviour or many health-related behaviours? Psychology Research and Behavior Management, 12, 23-30. https://doi.org/10.2147/PRBM. S173692

Huijts, T., Perkins, J. M., \& Subramanian, S. V. (2010). Political regimes, political ideology, and self-rated health in Europe: A multilevel analysis. PloS one, 5(7), e11711. https://doi.org/10.1371/journal.pone.0011711

Idler, E. L., \& Benyamini, Y. (1997). Self-rated health and mortality: A review of twenty-seven community studies. Journal of Health and Social Behavior, 38(1), 21-37. https://doi.org/10.2307/2955359

Iliffe, S., Tai, S. S., Haines, A., Gallivan, S., Goldenberg, E., Booroff, A., \& Morgan, P. (1992). Are elderly people living alone an at risk group? British Medical Journal, 305(6860), 1001-1004. https://doi.org/10.1136/ bmj.305.6860.1001

Isengard, B. (2013). The apple doesn't live far from the tree: Living distances between parents and their adult children in Europe. Comparative Population Studies, 38(2), 263-290. https://doi.org/10.4232/10. CPoS-2013-09de

Ivičević Uhernik, A., Skoko-Poljak, D., Dečković-Vukres, V., Jelavić, M., Mihel, S., Benjak, T., Štefančić, V., Draušnik, Ž., \& Stevanović, R. (2019). Association of poor self-perceived health with demographic, socioeconomic and lifestyle factors in the Croatian adult population. Društvena istraživanja, 28(2), 229-248. https://doi.org/10.5559/di.28.2.03

Jylhä, M. (2009). What is self-rated health and why does it predict mortality? Towards a unified conceptual model. Social Science $\mathcal{E}$ Medicine, 69(3), 307-316. https://doi.org/10.1016/j.socscimed.2009.05.013

Lara, J., McCrum, L. A., \& Mathers, J. C. (2014). Association of Mediterranean diet and other health behaviours with barriers to healthy eating and perceived health among British adults of retirement age. Maturitas 79(3), 292-298. https://doi.org/10.1016/j.maturitas.2014.07.003

Leon, A. S., \& Connett, J. (1991). Physical activity and 10.5 year mortality in the Multiple Risk Factor Intervention Trial (MRFIT). International Journal of Epidemiology 20(3), 690-697. https://doi.org/10.1093/ ije/20.3.690

Linardakis, M., Papadaki, A., Smpokos, E., Sarri, K., Vozikaki, M., \& Philalithis, A. (2015). Are religiosity and prayer use related with multiple behavioural risk factors for chronic diseases in European adults aged 50+ years? Public Health, 129(5), 436-443. https://doi.org/10. 1016/j.puhe.2015.02.006

Malter, F., \& Börsch-Supan, A. (Eds.) (2017). SHARE Wave 6: Panel innovations and collecting Dried Blood Spots. Munich: Munich Center for the Economics of Aging (MEA). Available at http://www.shareproject.org/fileadmin/pdf_documentation/MFRB_SHARE_Wave_6_ Panel_innovation/2017-01-17_SHARE-WAVE-6_E-Vers.pdf 
DRUŠ. ISTRAŽ. ZAGREB GOD. 29 (2020), BR. 2, STR. 217-239

ŠKARIĆ-JURIĆ, T. SMOLEJ NARANČ́IĆ, N., SMOLIĆ, Š: HEALTH-RISK...
Memel, M., Bourassa, K., Woolverton, C., \& Sbarra, D. A. (2016). Body mass and physical activity uniquely predict change in cognition for aging adults. Annals of Behavioral Medicine, 50(3), 397-408. https://doi.org/10.1007/s12160-015-9768-2

Miilunpalo, S., Vuori, I., Oja, P., Pasanen, M., \& Urponen, H. (1997). Self-rated health status as a health measure: The predictive value of self-reported health status on the use of physician services and on mortality in the working-age population. Journal of Clinical Epidemiology, 50(5), 517-528. https://doi.org/10.1016/S0895-4356(97)00045-0

Nolte, E., \& McKee, M. (2004). Changing health inequalities in east and west Germany since unification. Social Science \& Medicine, 58(1), 119-136. https://doi.org/10.1016/S0277-9536(03)00153-9

Pongiglione, B., \& Sabater, A. (2016). The role of education at young and older ages in explaining health inequalities in Europe. Population, Space and Place, 22(3), 255-275. https://doi.org/10.1002/psp.1899

Reher, D., \& Requena, M. (2018). Living alone in later life: A global perspective. Population and Development Review, 44(3), 427-454. https:// doi.org/10.1111/padr.12149

Reinhardt, U. (2003). Does the ageing of the population really drive the demand for health care? Health Affairs, 22(6), s27-39. https://doi. org/10.1377/hlthaff.22.6.27

Reuser, M., Bonneux, L. G., \& Willekens, F. J. (2009). Smoking kills, obesity disables: A multistate approach of the US Health and Retirement Survey. Obesity (Silver Spring), 17(4), 783-789. https://doi.org/ 10.1038/oby.2008.640

Richard, A., Rohrmann, S., Vandeleur, C. L., Schmid, M., Barth, J., \& Eichholzer, M. (2017). Loneliness is adversely associated with physical and mental health and lifestyle factors: Results from a Swiss national survey. PloS one, 12(7), e0181442. https://doi.org/10.1371/ journal.pone.0181442

Santos-Eggimann, B., Junod, J., \& Cornaz, S. (2005). Health service utilisation in older Europeans. In A. Börsch-Supan, A. Brugiavini, H. Jürges, J. Mackenbach, J. Siegrist, \& G. Weber (Eds.), Health, ageing and retirement in Europe. First results from the Survey of Health, Ageing and Retirement in Europe (pp. 133-140). Mannheim, Germany: Mannheim Research Institute for the Economics of Aging (MEA).

Schmitz, A. L., \& Pförtner, T. K. (2017). Health inequalities in old age: The relative contribution of material, behavioural and psychosocial factors in a German sample. Journal of Public Health, 40(3), e235-e243. https://doi.org/10.1093/pubmed/fdx180

Segel-Karpas, D. (2015). Number of illnesses, self-perceived health, and depressive symptoms: The moderating role of employment in older adulthood and old age. Work, Aging and Retirement, 1(4), 382-392. https://doi.org/10.1093/workar/wav009

Smolić, Š. (2017). The determinants of health among the population aged 50 and over: Evidence from Croatia. Public Sector Economics, 41(1), 86-108. https://doi.org/10.3326/pse.41.1.9

Södergren, M. (2013). Lifestyle predictors of healthy ageing in men. 
DRUŠ. ISTRAŽ. ZAGREB GOD. 29 (2020), BR. 2, STR. 217-239

ŠKARIĆ-JURIĆ, T. SMOLEJ NARANČ́IĆ, N., SMOLIĆ, Š.:

HEALTH-RISK...
Maturitas, 75(2), 113-117. https://doi.org/10.1016/j.maturitas.2013.02.011 Stolz, E., Mayerl, H., Waxenegger, A., \& Freidl, W. (2017). Explaining the impact of poverty on old-age frailty in Europe: Material, psychosocial and behavioural factors. European Journal of Public Health, 27(6), 1003-1009. https://doi.org/10.1093/eurpub/ckx079

Šućur, Z., \& Zrinščak, S. (2007). Differences that hurt: Self-perceived health inequalities in Croatia and European Union. Croatian Medical Journal, 48(5), 653-666. https://hrcak.srce.hr/index.php?show= clanak\&id_clanak_jezik $=32960$

Šverko, B., Galić, Z., \& Maslić Seršić, D. (2006). Nezaposlenost i socijalna isključenost: Longitudinalna studija (Unemployment and social exclusion: A longitudinal study). Revija za socijalnu politiku, 13(1), 1-14. https://doi.org/10.3935/rsp.v13i1.417

Thomeer, M. B., Mudrazija, S., \& Angel, J. L. (2016). Relationship status and long-term care facility use in later life. The Journals of Gerontology Series B: Psychological Sciences and Social Sciences, 73(4), e35-e36. https://doi.org/10.1093/geronb/gbw067

Turek, S., Rudan, I., Smolej Narančić, N., Szirovicza, L., Čubrilo-Turek, M., Žerjavić-Hrabak, V., Rak-Kaić, A., Vrhovski-Hebrang, D., Prebeg, Ž., Ljubičić, M., Janićijević, B., \& Rudan, P. (2001). A large cross-sectional study of health attitudes, knowledge, behaviour and risks in the post-war Croatian population (the First Croatian Health Project). Collegium Antropologicum, 25(1), 77-96. Available at https://hrcak.srce. $\mathrm{hr} / \mathrm{search} /$ ? show $=$ results\&stype $=1 \& \mathrm{c} \% 5 \mathrm{~B} 0 \% 5 \mathrm{D}=$ article_search\&t $\% 5 \mathrm{~B} 0 \% 5 \mathrm{D}=\mathrm{A}+$ large + cross-sectional + study + of + health + attitudes $\% 2 \mathrm{C}+$ knowledge $\% 2 \mathrm{C}+$ behaviour + and + risks + in + the + post-war + Croatian + population $+\% 28$ the + First + Croatian + Health + Project $\% 29$.

Vita, A. J., Terry, R. B., Hubert, H. B., \& Fries, J. F. (1998). Aging, health risks, and cumulative disability. The New England Journal of Medicine 338(15), 1035-1041. https://doi.org/10.1056/NEJM199804093381506

Vuletić, H., Polašek, O., Kern, J., Strnad, M., \& Baklaić, Z. (2009). Croatian Adult Health Survey - A tool for periodic cardiovascular risk factors surveillance. Collegium Antropologicum, 33 (Suppl 1), 2-9. https:// hrcak.srce.hr/index.php?show =clanak\&id_clanak_jezik $=62327$

Witvliet, M. I., Arah, O. A., Stronks, K., \& Kunst, A. E. (2014). Examining self-rated health of young central and eastern Europeans in the context of other world regions. European Journal of Public Health 24(2), 314-321. https://doi.org/10.1093/eurpub/ckt040

Zhang, H., Bago D'Uva, T., \& van Doorslaer, E. (2015). The gender health gap in China: A decomposition analysis. Economics and Human Biology, 18, 13-26. https://doi.org/10.1016/j.ehb.2015.03.001 
DRUŠ. ISTRAŽ. ZAGREB GOD. 29 (2020), BR. 2, STR. 217-239

ŠKARIĆ-JURIĆ, T. SMOLEJ NARANCĆIĆ, N., SMOLIĆ, Š.:

HEALTH-RISK...

\section{Zdravstveno rizična ponašanja i zdravlje stanovništva Hrvatske starijeg od 50 godina}

\author{
Tatjana ŠKARIĆ-JURIĆ, Nina SMOLEJ NARANČIĆ
} Institut za antropologiju, Zagreb

Šime SMOLIĆ

Ekonomski fakultet, Zagreb

Noviji podaci pokazuju da je samoprocjena zdravlja stanovnika Hrvatske značajno niža i da je razlika po spolu naglašenija nego u EU28. Stoga je cili ove studije bio ispitati odnos raznih karakteristika povezanih sa zdravljem sa dva pokazatelja zdravlja (subjektivnog i objektivnog) u stanovništvu Hrvatske starijem od 50 godina (2436 osoba, presječno istraživanje studije SHARE, 6. val). Analize logističke regresije napravljene su primjenom značajki ponašanja (prehrana, tjelesna aktivnost, pušenje, konzumacija alkohola), uz uključivanje odabranih društvenih i ekonomskih varijabli, te skale procjene kvalitete života (CASP-12). Nalazi upućuju na važnost intenzivne tjelesne aktivnosti i samoprocjene kvalitete života (CASP skala) kao dva obiliežja koja su se konzistentno pokazala važnima za objektivno i subjektivno zdravlje u oba spola. Kako je univarijatna povezanost većine ispitivanih elemenata ponašanja i zdravlia nestala u multivarijatnom modelu, zaključujemo da je takva povezanost samo neposredan odraz ekonomskih i psihosocijalnih čimbenika koji stoje u podlozi određenoga zdravstveno rizičnog ponašanja.

Rezultati ove studije pružaju dodatni argument za potrebu provedbe istraživanja zdravstvenih rizika unutar svake države posebno, jer je važnost određenih obilježja očito kulturno specifična.

Ključne riječi: SHARE, ponašanje povezano sa zdravljem, samoprocjena zdravlja, socioekonomski status, kvaliteta života

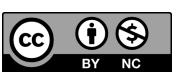

Međunarodna licenca / International License: Imenovanje-Nekomercijalno / Attribution-NonCommercial 